\title{
An assesment of domoic acid levels as a function of salinity-temperature variations in the Sea of Marmara
}

\author{
Marmara Denizi'ndeki domoik asit seviyelerinin tuzluluk-sıcaklık \\ değişimlerinin bir fonksiyonu olarak değerlendirilmesi
}

\section{Fuat Dursun}

Physical Oceanography and Marine Biology Department, Institute of Marine Sciences and Management, Istanbul University, 34134, Vefa, Fatih, Istanbul, Turkey

Abstract: This study presents the domoic acid (DA), responsible from Amnesic Shellfish Poisoning (ASP), levels of plankton net samples in the Sea of Marmara during April, July and October 2019. Plankton net samples were collected from 13 stations, which were located close to the Istanbul metropolitan area, and along the east and southwest parts of the Sea of Marmara. DA measurements were done by high-performance liquid chromatography (HPLC), using the diode-array detection (detection limit (LOD): $0.108 \mu \mathrm{g} \mathrm{mL}-1$ ). Twenty-two out of the 26 plankton net samples (84.6\%) were found to contain DA during the study period and the concentrations varied between 0.22 and $3.45 \mu \mathrm{g} \mathrm{mL}-1$. Possible relationships between physical parameters (salinitytemperature) and DA concentrations were investigated. DA production was mainly controlled by salinity (r:0.47, $p<0.05 ; n: 26)$ along the study period. These data may be used to consider the probability of finding similar conditions in different parts of the Sea of Marmara in order to determine the potential risks of DA to local mussel aquaculture and fisheries.

Keywords: Domoic acid, Pseudo-nitzschia, Sea of Marmara, HPLC

Öz: Bu çalışmada Nisan, Temmuz ve Ekim 2019 dönemlerinde Marmara Denizi'nden alınan plankton kepçe örneklerinde Amnezik Kabuklu Zehirlenmesi'ne (AKZ) neden olan denizel biyotoksin, domoik asit (DA), seviyeleri sunulmaktadır. Plankton kepçe örneklemeleri, Marmara Denizi'nin doğusunda, güneybatısında ve İstanbul metropol bölgesinin yakınında bulunan toplam 13 adet istasyondan yapılmışıı. Domoik asit ölçümleri, diode-array dedeksiyonu kullanılarak Yüksek Performansı Sıvı Kromatografisi yöntemiyle gerçekleştirimiş̧tir (Belirleme limiti: 0,108 $\mu \mathrm{g} \mathrm{mL}{ }^{-1}$ ). Çalışma dönemi boyunca alınan toplam 26 adet plankton kepçe örneğinden 22'sinin (\%84,6) DA içerdiği tespit edilmiş ve bu örneklerdeki konsantrasyon aralığı $0,22-3,45 \mu \mathrm{g} \mathrm{mL}{ }^{-1}$ olarak belirlenmiştir. DA konsantrasyonları ile fiziksel parametreler (tuzluluk ve sıcaklık) arasındaki olası ilişkiler incelenmiş ve çalışma dönemi boyunca DA üretiminin genel olarak tuzluluk $(r: 0,47, p<0,05 ; n: 26)$ tarafından kontrol edildiği tespit edilmiştir. Çalışma sonucunda elde edilen bu veriler, Marmara Denizi'nin farkı bölgelerinde de aynı koşulların bulunma olasılı̆ııın değerlendirilmesinde kullanılabileceği gibi, yerel midye yetiştiricilik ve balıkçılık alanlarındaki potansiyel riskleri belirlemek açısından da kullanılabilecektir.

Anahtar kelimeler: Domoik asit, Pseudo-nitzschia, Marmara Denizi, HPLC

\section{INTRODUCTION}

Domoic acid (DA), a naturally occuring neurotoxin, was first isolated from the red macroalgae Chondria armata (Takemoto and Daigo, 1958). This tricarboxylic neurotoxin is a crystalline water-soluble amino acid with a secondary amino group and belongs to the kainoid class of compounds (Saeed et al., 2017). DA can be transferred via the food web and cause amnesic shellfish poisoning (ASP) in humans. ASP, is a kind of intoxication with gastrointestinal symptoms (vomiting and diarrhea) and following neurological disorders (short time memory loss and coma) on humans (Lefebvre and Robertson, 2010). Perl et al., (1990) reported the first ASP case in Prince Edward Island, Canada in 1987, over 100 people were sickened and three died, after the consumption of DA contaminated blue mussels (Mytilus edulis). Also, DA accumulated in filter feeders can be harmful to higher trophic levels, such as sea lions, whales and birds (Fire et al., 2010; Scholin et al., 2000). Since the incident in Canada, growing number of cases has been reported and DA widely investigated in many regions of South America (Buck, 1992; Hallegraeff, 2004), Europe (Klein et al., 2010; Vrieling et al., 1996), Australia (Lapworth et al., 2001), North Africa (Sahraoui et al., 2012) and Asia (Likumahua et al., 2019).

Pseudo-nitzschia, a chain forming diatom genus, is among the most widely distribute members of marine phytoplankton communites around the world (Almandoz et al., 2008; Hasle, 2002; Kudela et al., 2004; Ljubešić et al., 2011; Teng et al., 2014; Tenorio et al., 2016). The last reported total number of identified Pseudo-nitzschia species is 52 of which 26 are thought to be capable of producing DA (Bates et al., 2018). Moreover, many studies have reported that the toxic species of the genus Pseudo-nitzschia are frequent members of the phytoplankton community in the Golden Horn Estuary and Sea of Marmara in recent years (Dursun and Tas, 2019; Tas et al., 2016; Tas and Lundholm, 
2017; Tas and Yilmaz, 2015). Furthermore, many studies have shown the importance of a variety of factors such as temperature (Lewis et al., 1993), salinity (Thessen et al., 2005), pH (Lundholm et al., 2004) and nutrients (Bates et al., 1991). Thus, it is essential to understand the factors that stimulate Pseudo-nitzschia growth and DA production.

The Sea of Marmara, an inland sea, is a transition zone between the Black Sea and the Mediterranean Sea (Figure 1). It is located between Europe and Asia, and together with the Dardanelles and Bosphorus forms the 'Turkish Strait System'(Beşiktepe et al., 1994). The characteristic of the system is the permanent stratification seperating the Black Sea originated less saline upper layer ( $18 \mathrm{psu}$ ) from the saline Mediterranean waters ( $38 \mathrm{psu}$ ) of the lower layer (Ünlülata et al., 1990). It is under dense anthropogenic pollution pressure and it has numerous fragile bays where frequent algal blooms have frequently been observed. Furthermore, the industrialized regions of the Gulf of Izmit, and Gemlik, Bandirma, Erdek and Tekirdag Bays are some of the most densely populated coastal regions in Turkey. Thus, these regions constitute a unique and complex experimental site for examining the relation between natural and anthropogenic factors influencing the development of harmful algal blooms in coastal waters. Phytoplankton monitoring is conducted in the region since 1990s revealing potentially toxic genera, such as Alexandrium, Gymnodinium, Dinophysis, and Pseudo-nitzschia has been by microscopy (Aktan et al., 2005; Deniz and Tas, 2009). However, the monitoring programs was only focused on the abundance and distribution of phytoplankton with particular attention to harmful and toxic species, nor did it include associated toxin analyses.

Until now, DA production has been reported in Golden Horn Estuary, Turkey (Dursun et al., 2017, 2018; Tas et al., 2016). Only one study has revealed the relationship between DA and environmental factors and it focused on the smaller parts of the Sea of Marmara (Dursun et al., 2016). On the other hand, environmental factors that promote the production of DA are very complex and can be unique to regions (bays, gulfs, coastal zones or open seas) and seasons (Trainer et al., 2012). This complexity and varying environmental factors needs broader areas and further investigations. To our knowledge, no detailed and particular study addressed DA levels in the Sea of Marmara, including the Istanbul metropolitan area, east and southwest part of the region. On the other hand, the coast along the Sea of Marmara has a large human population that consumes fish and other seafood products, making them potentially vulnerable to ASP.

Given the complete lack of information on potential DA levels in the Sea of Marmara, the present study firstly addressed the possible presence and variability of domoic acid in plankton net samples. Secondly, physical parameters that might regulate the production and variability of DA were investigated. For this purposes, seasonal cruises were conducted at 13 stations, which represents spring (April 2019), summer (July 2019) and autumn (October 2019) conditions, water column properties as well as DA concentrations were analysed.

\section{MATERIALS AND METHODS}

\section{Field sampling}

Seasonal cruises were conducted in the Sea of Marmara during spring (April 2019), summer (July 2019) and autumn (October 2019). Plankton net samples were collected from 13 stations (Table 1) which were located close to the Istanbul metropolitan area (ST1-ST4), and along the east and (ST5ST9) southwest parts of the Sea of Marmara (ST10-ST13) (Figure 1). The selection of the sampling sites was based on different criteria related to the hydrological regime and the localization of urban and industrial discharges. Plankton net samples were obtained from the $20 \mathrm{~m}$ depth to the surface (upper layer) vertically with a Nansen net ( $57 \mu \mathrm{m}$ mesh size, $55 \mathrm{~cm} \varnothing$ ). A sample volume between 25 and $180 \mathrm{~mL}$ was filtered through a Whatman GF/C $(0.45 \mu \mathrm{m}, 47 \mathrm{~mm} \varnothing)$ glass fiber filter then kept at $-20^{\circ} \mathrm{C}$ until extraction and HPLC analysis (Bates et al., 1991). As physical indicators, temperature and salinity measurements were recorded using a SBE 911 plus CTD system and a multi-parameter probe (YSI Professional Pro Plus) to trace changes in physical conditions, which could act as a trigger for domoic acid production (Dursun et al., 2016). All environmental data were used as the average of 0-20 $\mathrm{m}$ depths.

\section{Toxin extraction and analysis in plankton samples}

Duplicate portions of plankton net samples were filtered through a $47 \mathrm{~mm}$ Whatman GF/C filter to determine domoic acid concentrations in plankton samples. The filter was rolled, placed in a test tube and kept frozen until analysis. Samples were extracted according to the procedure described by Milley et al. (1990), that is, extracted with $5 \mathrm{~mL} \mathrm{50 \%} \mathrm{(v/v)}$ aqueous methanol, vortexed for $2 \mathrm{~min}$ and centrifuged at $4000 \mathrm{rpm}$ for $10 \mathrm{~min}$ at $20^{\circ} \mathrm{C}$. The supernatant was filtered through a Millex-GS $0.22 \mu \mathrm{m}$ disposable filter (if necessary) into a vial and $20 \mu \mathrm{L}$ were injected into the column.

Table 1. List of the sampling stations

\begin{tabular}{lclc}
\hline Sampling date & Station & Region & $\begin{array}{c}\text { Depth } \\
(\mathbf{m})\end{array}$ \\
\hline April, October 2019 & ST1 & Kucukcekmece & 38 \\
April, October 2019 & ST2 & Buyukcekmece & 50 \\
April, October 2019 & ST3 & Princes' Islands & 96 \\
April, October 2019 & ST4 & Tuzla & 93 \\
April, October 2019 & ST5 & Yalova coast & 57 \\
April, October 2019 & ST6 & Cinarcik & 1267 \\
April, October 2019 & ST7 & Gemlik Bay & 100 \\
April, October 2019 & ST8 & Imrali Island (Northwest) & 200 \\
April, October 2019 & ST9 & Imrali Island (West) & 46 \\
April, July 2019 & ST10 & Marmara Island (North) & 90 \\
April, July 2019 & ST11 & Marmara Island (West) & 70 \\
April, July 2019 & ST12 & Pasalimani Island (South) & 40 \\
April, July 2019 & ST13 & Avsa Island (Southwest) & 60 \\
\hline
\end{tabular}


Chromatographic analysis were performed using a Hewlett-Packard (HP) Model 1100 equipped with an inline degasser, quaternary pump, autosampler and diode-array detector; data collection and results processing were performed using the HP Chemstation software. Toxins were separated on a Macherey-Nagel Nucleodour 100 RP-C18 ( $250 \mathrm{~mm} \times 4.6 \mathrm{~mm}, 5 \mu \mathrm{m})$ column. Detection wavelength was set at $242 \mathrm{~nm}$ with a $10 \mathrm{~nm}$ band width; the reference wavelength was $450 \mathrm{~nm}$ with a $100 \mathrm{~nm}$ bandwidth. The mobile phases were Milli-Q water plus $0.1 \% \quad(\mathrm{v} / \mathrm{v})$ trifluoroacetic acid (TFA) and acetonitrile (MeCN) plus $0.1 \%$ TFA. The flow rate was set at $0.4 \mathrm{~mL} \mathrm{~min}^{-1}$. Gradient elution was programmed at $25 \% \mathrm{MeCN}$, maintained for $15 \mathrm{~min}$ and increased to $50 \%$ over 15 min, which was maintained for 5 min. Elution was then followed by an increase to $100 \% \mathrm{MeCN}$ over 5 min before programming back to initial conditions over $5 \mathrm{~min}$. Initial conditions were maintained for a further $5 \mathrm{~min}$, resulting in a total cycle time of $30 \mathrm{~min}$ according to Tas et al. (2016). DA has a retention time of $8.8 \mathrm{~min}$. The seven-point calibration curve was linear for the range $0.125-10 \mu \mathrm{g} \mathrm{mL}^{-1}$ $\left(r^{2}: 0.99, n: 3\right)$. The LOD, based on a signal to noise ratio of 3.3 , was $0.108 \mu \mathrm{g} \mathrm{mL}^{-1}$ and limit of quantification (LOQ) was $0.326 \mu \mathrm{g} \mathrm{mL} \mathrm{m}^{-1}$. DA concentrations were examined by Pearson Product-Moment Correlation analysis for their relationships with physical parameters. Data analyses were conducted using the Software package STATISTICA 6.0.

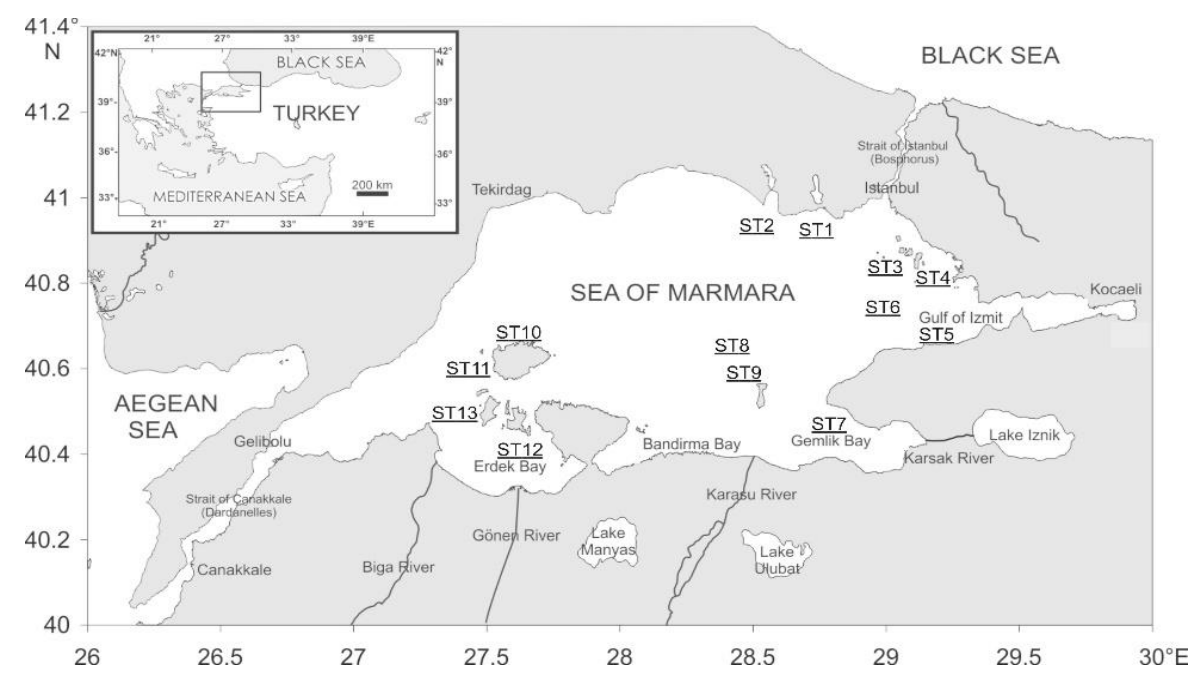

Figure 1. Map of the study area showing the location of the sampling stations in the Sea of Marmara

\section{RESULTS AND DISCUSSION}

Average $(0-20 \mathrm{~m})$ salinity showed a slightly spatial and remarkably seasonal pattern during the study period, ranging between 16.60 (ST11, July 2019) and 28.10 (ST4, October 2019) (Figure 2a). Average salinity was relatively stable between 24.40 and 26.00 during April 2019, decreased slightly to 22.10 in July 2019 and started to increase 26.90 at the end of the sampling period (October 2019).

Average (0-20 m) water temperatures showed a seasonal pattern during the study period, ranging between $10.7^{\circ} \mathrm{C}$ (ST13, April 2019) and $23.4^{\circ} \mathrm{C}$ (ST12, July 2019) (Figure 2b). During April 2019 , the average temperature was $11.9^{\circ} \mathrm{C}$, increased remarkably to $21.2^{\circ} \mathrm{C}$ in July 2019 and started to decrease $19.4^{\circ} \mathrm{C}$ at the end of the sampling period (October 2019). The highest difference between the stations were recorded at stations ST10, ST11, ST12 and ST13, which were located at southwest part of the Sea of Marmara.

HPLC chromatograms clearly demonstrated the presence of DA in plankton net samples (Figure 3). Twenty-two out of the 26 plankton net samples $(84.6 \%)$ were found to contain DA during April and October 2019, but no DA was detected during July 2019 at the southwest part of the Sea of Marmara.

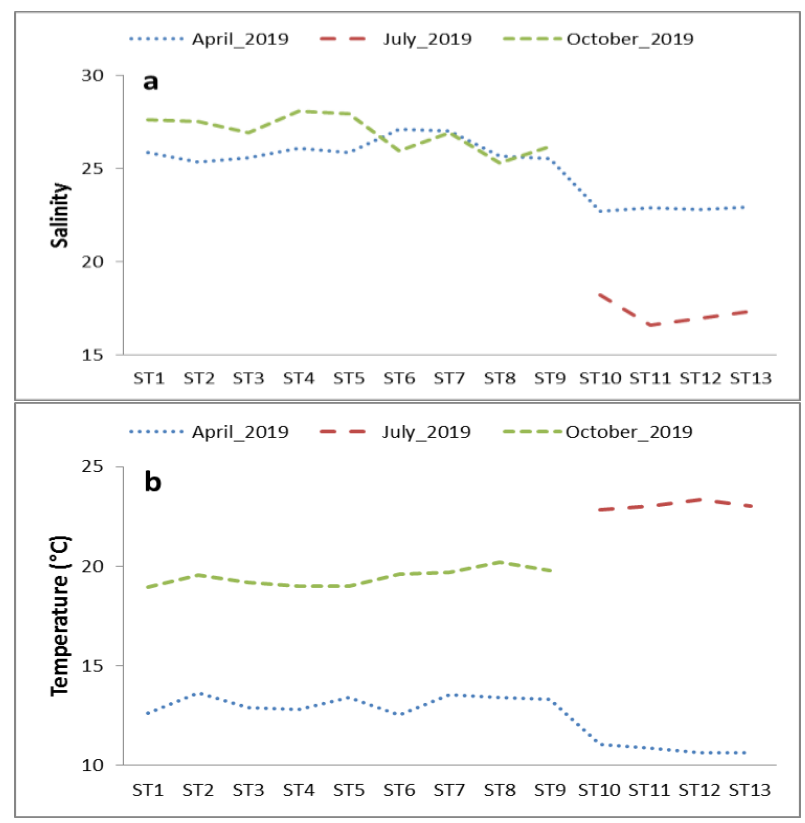

Figure 2. Changes in salinity (a) and temperature (b) during the study period 


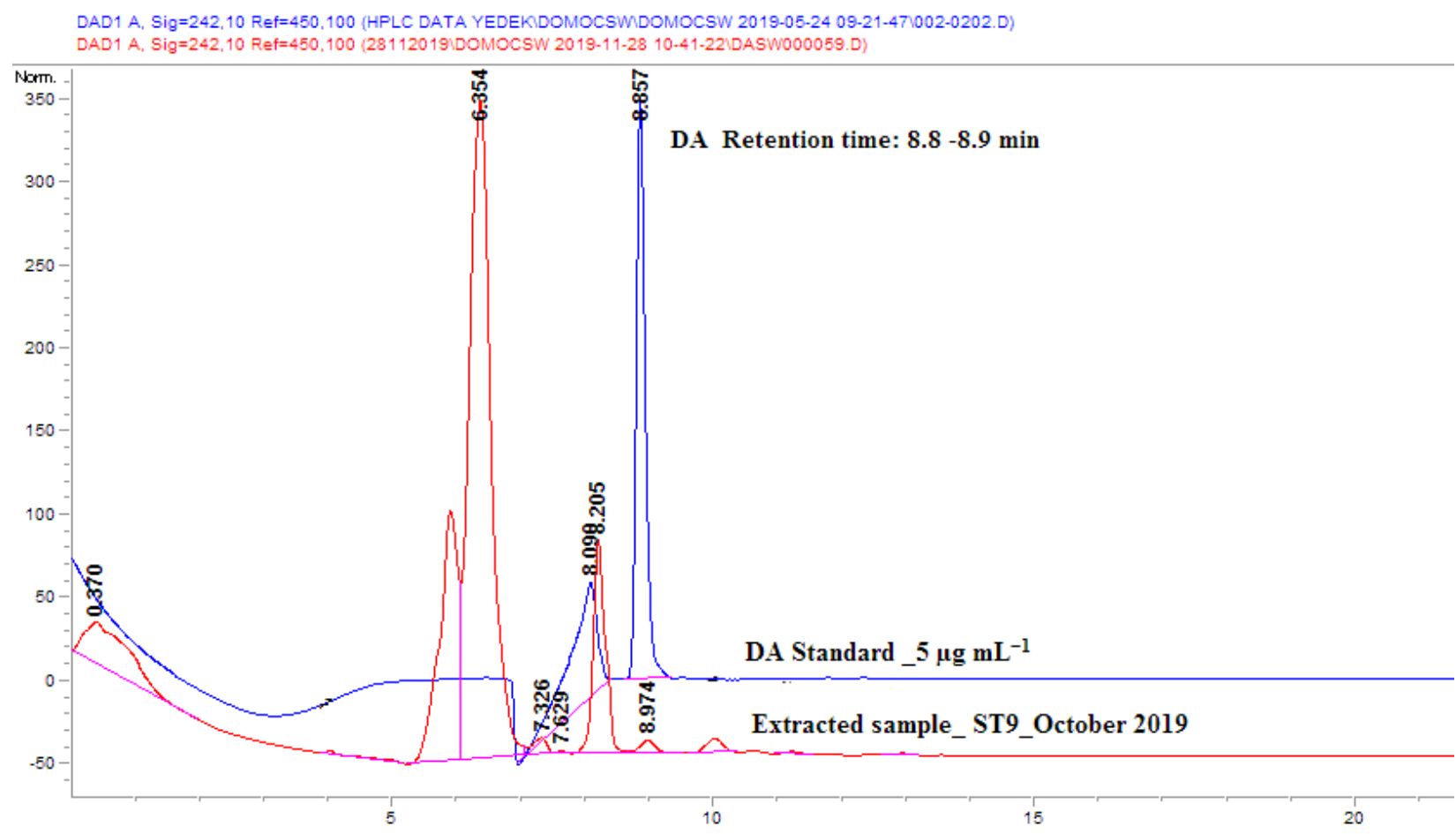

Figure 3. The HPLC-DAD chromatograms of DA standard (blue line) and plankton net sample extract (red line)

DA levels showed significant seasonal variation, and the concentrations varied between 0.22 and $1.27 \mu \mathrm{g} \mathrm{mL}-1$ in April 2019 and $0.89-3.45 \mu \mathrm{g} \mathrm{mL}-1$ in October 2019 (Figure 4). DA levels were generally higher during October 2019 and the highest concentrations (2.66 and $3.45 \mu \mathrm{g} \mathrm{mL}-1$ ) were observed at stations ST8 and ST9, which were located along the east part of the Sea of Marmara (Figure 4). Lower range of DA concentrations were measured in April 2019, with a mean of $0.89 \mu \mathrm{g} \mathrm{mL}^{-1}$ at the stations ST10, ST11, ST12 and ST13, which were located southwest part of the Sea of Marmara. When compared with other stations, ST8 (Imrali Island, Northwest) and ST9 (Imrali Island, West) are not close to the Istanbul metropolitan area and under the effect of inputs via industry and/or rivers. Also these results agree with the Bates et al. (1991) which reported the higher DA concentrations at offshore stations. DA distribution is not associated with highly elevated nutrient concentrations and chlorophyll-a peaks characteristics of the coastal waters immediately affected by the river inputs (Bates et al., 1991). Thus, these differences may stimulate the production of DA at these stations in the Sea of Marmara.

In recent years, some studies have reported DA concentrations, collected samples by plankton net, from different regions of the world. Toxic species of Pseudonitzschia have been reported from Lisbon Bay, Portugal (Vale and Sampayo, 2001), Queensland, Australia (Takahashi et al., 2007), Nha Phu Bay, Vietnam (Dao et al., 2009) and Sea of Marmara (Dursun et al., 2016) with highest values of 700 , 120, 12 and $5.25 \mu \mathrm{gL} \mathrm{m}^{-1}$, respectively. Sampling depth and region, sample volume and collection methods can affect DA levels. In this study, plankton sampling was conducted with 55 $\mu \mathrm{m}$ mesh size of plankton net instead of commonly used 20 $\mu \mathrm{m}$ mesh size and maximum value was measured as $3.45 \mu \mathrm{g}$ $\mathrm{mL}^{-1}$. Our results are expected to be more similar to the results of Takahashi et al. (2007) and Dursun et al. (2016), which may be due to the fact that phytoplankton samples were collected in both studies with similar mesh-sized plankton nets. However, in this study, DA concentrations were detected as high as in different regions (Schnetzer et al., 2007; Trainer et al., 2000) faced with DA toxicity events, with maximum values of $<1.5 \mu \mathrm{g} \mathrm{mL}-1$.

It has previously been reported that Pseudo-nitzschia genus is the regular and frequent member of phytoplankton assemblages in the Sea of Marmara and, abundances varied between $1 \times 10^{3}$ and $186 \times 10^{3}$ cells L-1 (Deniz and Tas, 2009; Taş et al., 2011). Some species of the genus have the ability to produce DA (Dursun et al., 2016). On the other hand, no ASP case has ever documented in the Sea of Marmara, in spite of the presence of toxic Pseudo-nitzschia species. Despite the current conditions appearing to be unfavourable for the formation of dense and highly toxic blooms of Pseudonitzschia in the Sea of Marmara, it is known that physical factors can stimulate DA production in different ways, as Granéli and Flynn (2006) and Macintyre et al. (2011) stated. It can be said that differences in DA levels between the regions due to the changes in environmental conditions including temperature and salinity. Pearson correlation analysis showed that DA production was mainly controlled by salinity ( $r: 0.47, p<0.05 ; n: 26)$ along the study period. But no correlation was found between temperature and DA. This 
relationship is similar to study which is reported by Busse et al. (2006) for San Diego, California and Dursun et al. (2016), for the Sea of Marmara during February 2011; but also it differs from the data given for the Golden Horn Estuary between August 2011 and July 2012 by Dursun et al. (2018).

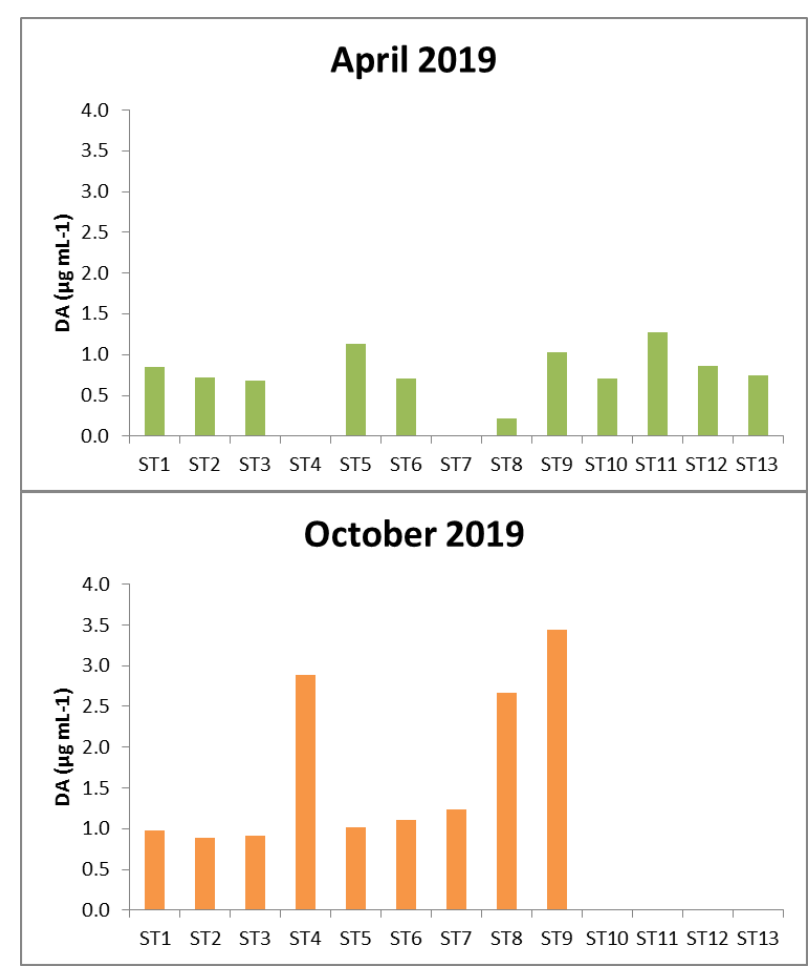

Figure 4. The spatio-temporal distributions of domoic acid levels in plankton net samples

Here, the results of preliminary research related to the DA production in the Sea of Marmara were presented. Even when the sampling was not exhaustive, domoic acid was

\section{REFERENCES}

Aktan, Y., Tüfekçi, V., Tüfekçi, H. \& Aykulu, G. (2005). Distribution patterns, biomass estimates and diversity of phytoplankton in Izmit Bay (Turkey). Estuarine, Coastal and Shelf Science, 64(2-3), 372-384. DOl:10.1016/j.ecss.2005.03.003

Almandoz, G. O., Ferreyra, G.A., Schloss, I.R., Dogliotti, A.I., Rupolo, V., Paparazzo, F.E., \& Ferrario, M.E. (2008). Distribution and ecology of Pseudo-nitzschia species (Bacillariophyceae) in surface waters of the Weddell Sea (Antarctica). Polar Biology, 31(4), 429-442. DOI:10.1007/s00300-007-0369-9

Bates, S., Freitas, A.S.W. de, Milley, J.E., Pocklington, R., Quilliam, M.A., Smith, J.C. \& Worms, J. (1991). Controls on Domoic Acid Production by the Diatom Nitzschia pungens f. multiseries in Culture: Nutrients and Irradiance. Canadian Journal of Fisheries and Aquatic Sciences, 48(7), 1136-1144. DOI:10.1139/f91-137

Bates, S., Hubbard, K.A., Lundholm, N., Montresor, M. \& Leaw, C.P. (2018). Pseudo-nitzschia, Nitzschia, and domoic acid: New research since 2011. Harmful Algae, 79, 3-43. DOI:10.1016/.jhal.2018.06.001

Beşiktepe, Ş., Sur, H.I., Özsoy, E., Latif, M.A., Oğuz, T. \& Ünlüata, Ü. (1994). The circulation and hydrography of the Marmara Sea. Progress in Oceanography, 34(4), 285-334. DOI:10.1016/0079-6611(94)90018-3 found to be present in plankton samples collected during April and October 2019. This means that the human population and the shellfish resources could be affected by amnesic shellfish poisoning. This study shows the importance of understanding the DA production process in relation to the physical conditions in plankton net samples. However, more investigation containing all environmental variables is needed to get a clear understanding of DA production.

This work did not include the detection of DA accumulation in shellfish and fish species, but that would be a logical step for further studies on DA production in the Sea of Marmara. There have not yet been any reports of illness in humans or marine life due to DA poisoning in the region. Even if the DA concentrations are generally low, there is a potential for toxin production to occur in this region. Thus, more research is needed to confirm the capacity of the genus Pseudo-nitzschia in coastal waters of Turkey to produce DA, since this species exists in phytoplankton blooms. It is very important to understand better and manage the impact of potential harmful algal blooms, and in order to prevent human intoxication and losses to aquaculture.

\section{ACKNOWLEDGEMENTS}

This work was partially supported by the Institute of Marine Sciences and Management, Istanbul University (IMSM-IU) and Scientific Research Projects Coordination Unit of Istanbul University (Grant number: FBA-2018-30845). I am very grateful to Dr. Hüsne Altıok for CTD measurements in the field. Also, I would like to thank R/V ALEMDAR II staff, other colleagues and students, who was on the board during April and October 2019 cruises, for their assistance with the field work. I would like to thank Dr. Nazlı Demirel for giving me the opportunity to attend field surveys with the vessel "Şükriye Ana-Il", during April and July 2019.
Buck, K.R. (1992). Autecology of the diatom Pseudonitzschia australis, a domoic acid producer, from Monterey Bay, California. Marine Ecology Progress Series, 84(3), 293-302. DOI:10.3354/meps084293

Busse, L.B., Venrick, E.L., Antrobus, R., Miller, P.E., Vigilant, V., Silver, M.W., \& Prezelin, B.B. (2006). Domoic acid in phytoplankton and fish in San Diego, CA, USA. Harmful Algae, 5(1), 91-101. DOI:10.1016/j.hal.2005.06.005

Dao, H.V., Takata, Y., Omura, T., Sato, S., Fukuyo, Y. \& Kodama, M. (2009). Seasonal variation of domoic acid in a bivalve Spondylus versicolor in association with that in plankton samples in Nha Phu Bay, Khanh Hoa, Vietnam. Fisheries Science, 75(2), 507-512. DOI:10.1007/s12562-009-0057-5

Deniz, N. \& Tas, S. (2009). Seasonal variations in the phytoplankton community in the north-eastern sea of marmara and a species list. Journal of the Marine Biological Association of the United Kingdom, 89(2), 269-276. DOI:10.1017/S0025315409003117

Dursun, F., Yurdun, T. \& Ünlü, S. (2016). The First Observation of Domoic Acid in Plankton Net Samples from the Sea of Marmara, Turkey. Bulletin of Environmental Contamination and Toxicology, 96(1), 70-75. DOI:10.1007/s00128-015-1704-4 
Dursun, F., Ünlü, S., Tas, S. \& Yurdun, T. (2017). Domoic acid variations in response to environmental conditions in an eutrophic estuary, Golden Horn (Turkey). Turkish Journal of Fisheries and Aquatic Sciences, 17(4), 653-662. DOI:10.4194/1303-2712-v17_4_01

Dursun, F., Ünlü, S. \& Yurdun, T. (2018). Determination of Domoic Acid in Plankton Net Samples from Golden Horn Estuary, Turkey, Using HPLC with Fluorescence Detection. Bulletin of Environmental Contamination and Toxicology, 100(3), 457-462. DOI:10.1007/s00128-018-2275-y

Dursun, F. \& Tas, S. (2019). Variations in abundance and diversity of phytoplankton in the surface waters of the Golden Horn Estuary (Sea of Marmara). Journal of the Marine Biological Association of the United Kingdom, 99(2), 279-290. DOI:10.1017/S0025315418000073

Fire, S.E., Wang, Z., Berman, M., Langlois, G.W., Morton, S.L., SekulaWood, E. \& Benitez-Nelson, C. R. (2010). Trophic transfer of the harmful algal toxin domoic acid as a cause of death in a minke whale (Balaenoptera acutorostrata) stranding in southern California. Aquatic Mammals, 36(4), 342-350. DOI:10.1578/AM.36.4.2010.342

Granéli, E. \& Flynn, K. (2006). Chemical and Physical Factors Influencing Toxin Content. In Ecology of Harmful Algae (pp. 229-241). DOI:10.1007/978-3-540-32210-8_18

Hallegraeff, G.M. (2004). Harmful algal blooms: a global overview. Manual on Harmful Marine Microalgae, 33, 1-22.

Hasle, G.R. (2002). Are most of the domoic acid-producing species of the diatom genus Pseudo-nitzschia cosmopolites? Harmful Algae, 1(2), 137-146. DOI:10.1016/S1568-9883(02)00014-8

Klein, C., Claquin, P., Bouchart, V., Le Roy, B. \& Véron, B. (2010). Dynamics of Pseudo-nitzschia spp. and domoic acid production in a macrotidal ecosystem of the Eastern English Channel (Normandy, France). Harmful Algae, 9(2), 218-226. DOI:10.1016/j.hal.2009.10.004

Kudela, R., Roberts, a, \& Armstrong, M. (2004). Laboratory analyses of nutrient stress and toxin accumulation in Pseudo-nitzschia species from Monterey Bay, California. Harmful Algae 2002, 136-138.

Lapworth, C., Hallegraeff, G.M.J., \& Ajani, P.A. (2001). Identification of domoic-acid-producing Pseudo-nitzschia species in Australian waters. In Harmful Algal Blooms 2000 Proceedings of the Ninth International Conference on Harmful Algal Blooms (pp. 38-41).

Lefebvre, K.A. \& Robertson, A. (2010). Domoic acid and human exposure risks: A review. Toxicon, 56(2), 218-230 DOI:10.1016/j.toxicon.2009.05.034

Lewis, N., Bates, S., Mclachlan, J. \& Smith, J. (1993). Temperature effects on growth, domoic acid production, and morphology of the diatom Nitzschia pungens $\mathrm{f}$. multiseries. In: Toxic phytoplankton blooms in the sea (Ed. by T.J. Smayda \& Y. Shimizu). In Elsevier Science Publishers B.V (pp. 601-606).

Likumahua, S., de Boer, M.K., Krock, B., Nieuwenhuizen, T., Tatipatta, W.M., Hehakaya, S., \& Buma, A.G.J. (2019). First record of the dynamics of domoic acid producing Pseudo-nitzschia spp. in Indonesian waters as a function of environmental variability. Harmful Algae, 90 DOl:10.1016/j.hal.2019.101708

Ljubešić, Z., Bosak, S., Viličić, D., Borojević, K.K., Marić, D., Godrijan, J., \& Dakovac, T. (2011). Ecology and taxonomy of potentially toxic Pseudonitzschia species in Lim Bay (north-eastern Adriatic Sea). Harmful Algae, 10(6), 713-722. DOI:10.1016/j.hal.2011.06.002

Lundholm, N., Hansen, P.J., \& Kotaki, Y. (2004). Effect of pH on growth and domoic acid production by potentially toxic diatoms of the genera Pseudo-nitzschia and Nitzschia. Marine Ecology Progress Series, 273, 1-15. DOI:10.3354/meps273001

Macintyre, H.L., Stutes, A.L., Smith, W.L., Dorsey, C.P., Annabraham, \& Dickey, R.W. (2011). Environmental correlates of community composition and toxicity during a bloom of Pseudo-nitzschia spp. in the northern Gulf of Mexico. Journal of Plankton Research, 33(2), 273-295. DOI:10.1093/plankt/fbq146

Milley, J.E., Bates, S., Bird, C.J., De Freitas, A.S.W. \& Quilliamt, M.A. (1990). Trace determination of domoic acid in seawater and phytoplankton by high-performance liquid chromatography of the fluorenylmethoxycarbonyl (fmoc) derivative. International Journal of Environmental Analytical Chemistry, 38(3), 351-368. DOI:10.1080/03067319008026940

Perl, T.M., Bédard, L., Kosatsky, T., Hockin, J.C., Todd, E.C.D. \& Remis, R.S. (1990). An Outbreak of Toxic Encephalopathy Caused by Eating Mussels Contaminated with Domoic Acid. New England Journal of Medicine, 322(25), 1775-1780. DOI:10.1056/nejm199006213222504

Saeed, A.F., Awan, S.A., Ling, S., Wang, R. \& Wang, S. (2017). Domoic acid: Attributes, exposure risks, innovative detection techniques and therapeutics. Algal Research, 24, 97-110. DOI:10.1016/j.algal.2017.02.007

Sahraoui, I., Grami, B., Bates, S., Bouchouicha, D., Chikhaoui, M.A., Mabrouk, H.H. \& Hlaili, A. S. (2012). Response of potentially toxic Pseudo-nitzschia (Bacillariophyceae) populations and domoic acid to environmental conditions in a eutrophied, SW Mediterranean coastal lagoon (Tunisia). Estuarine, Coastal and Shelf Science, 102-103, 95104. DOI:10.1016/j.ecss.2012.03.018

Schnetzer, A., Miller, P.E., Schaffner, R.A., Stauffer, B.A., Jones, B.H., Weisberg, S.B., ... Caron, D.A. (2007). Blooms of Pseudo-nitzschia and domoic acid in the San Pedro Channel and Los Angeles harbor areas of the Southern California Bight, 2003-2004. Harmful Algae, 6(3), 372-387. DOI:10.1016/j.hal.2006.11.004

Scholin, C.A., Gulland, F., Doucette, G.J., Benson, S., Busman, M., Chavez, F.P., \& Van Dolah, F.M. (2000). Mortality of sea lions along the central California coast linked to a toxic diatom bloom. Nature, 403(6765), 8084. DOI:10.1038/47481

Takahashi, E., Yu, Q., Eaglesham, G., Connell, D.W., McBroom, J., Costanzo, S., \& Shaw, G. R. (2007). Occurrence and seasonal variations of algal toxins in water, phytoplankton and shellfish from North Stradbroke Island, Queensland, Australia. Marine Environmental Research, 64(4), 429-442. DOI:10.1016/j.marenvres.2007.03.005

Takemoto, T. \& Daigo, K. (1958). Constituents of Chondria armata. Chemical and Pharmaceutical Bulletin, 6(5), 578-580. DOI:10.1248/cpb.6.578b

Taş, S., Okuş, E., Ünlü, S. \& Altiok, H. (2011). A study on phytoplankton following Volgoneft-248 oil spill on the north-eastern coast of the Sea of Marmara. Journal of the Marine Biological Association of the United Kingdom, 91(3), 715-725. DOI:10.1017/S0025315410000330

Tas, S. \& Yilmaz, I.N. (2015). Potentially harmful microalgae and algal blooms in a eutrophic estuary in the Sea of Marmara (Turkey). Mediterranean Marine Science, 16(2), 432-443. DOI:10.12681/mms.1042

Tas, S., Dursun, F., Aksu, A. \& Balkis, N. (2016). Presence of the diatom genus Pseudo-nitzschia and particulate domoic acid in the Golden Horn Estuary (Sea of Marmara, Turkey). Diatom Research, 31(4), 339-349. DOI:10.1080/0269249X.2016.1247020

Tas, S. \& Lundholm, N. (2017). Temporal and spatial variability of the potentially toxic Pseudo-nitzschia spp. in a eutrophic estuary (Sea of Marmara). Journal of the Marine Biological Association of the United Kingdom, 97(7), 1483-1494. DOI:10.1017/S0025315416000837

Teng, S.T., Lim, H.C., Lim, P.T., Dao, V.H., Bates, S. \& Leaw, C. P. (2014). Pseudo-nitzschia kodamae sp. nov. (Bacillariophyceae), a toxigenic species from the strait of Malacca, Malaysia. Harmful Algae, 34, 17-28. DOI:10.1016/j.hal.2014.02.005

Tenorio, C., Uribe, E., Gil-Kodaka, P., Blanco, J. \& Álvarez, G. (2016). Morphological and toxicological studies of Pseudo-nitzschia species from the central coast of Peru. Diatom Research, 31(4), 331-338. DOI:10.1080/0269249X.2016.1247018

Thessen, A.E., Dortch, Q., Parsons, M.L. \& Morrison, W. (2005). Effect of salinity on Pseudo-nitzschia species (Bacillariophyceae) growth and distribution. Journal of Phycology, 41(1), 21-29. DOI:10.1111/j.1529-8817.2005.04077.x

Trainer, V.L., Adams, N.G., Bill, B.D., Stehr, C.M., Wekell, J.C., Moeller, P., \& Woodruff, D. (2000). Domoic acid production near California coastal upwelling zones, June 1998. Limnology and Oceanography, 45(8), 1818-1833. DOI:10.4319/lo.2000.45.8.1818

Trainer, V.L., Bates, S., Lundholm, N., Thessen, A.E., Cochlan, W.P., Adams, N.G. \& Trick, C. G. (2012). Pseudo-nitzschia physiological 
ecology, phylogeny, toxicity, monitoring and impacts on ecosystem health. Harmful Algae, 14, 271-300. DOl:10.1016/j.hal.2011.10.025

Ünlülata, Ü., Oğuz, T., Latif, M.A. \& Özsoy, E. (1990). On the Physical Oceanography of the Turkish Straits. In The Physical Oceanography of Sea Straits (pp. 25-60). DOI:10.1007/978-94-009-0677-8_2

Vale, P. \& Sampayo, M.A.M. (2001). Domoic acid in Portuguese shellfish and fish. Toxicon, 39(6), 893-904. DOl:10.1016/S0041-0101(00)00229-4
Vrieling, E.G., Gieskes, W.W.C., Vrieling, E.G., Veenhuis, M., Koeman, R.P.T., Scholin, C. A., \& Peperzak, L. (1996). Identification of a domoic acid-producing pseudo-nitzschia species (bacillariophyceae) in the dutch wadden sea with electron microscopy and molecular probes. European Journal of Phycology, 31(4), 333-340. DOI:10.1080/09670269600651561 